\title{
THE CENSORIAL CONTROL - SUFFICIENT FOR A NON-PROFIT ORGANISATION
}

\author{
Nicolae Todea ${ }^{l}$ \\ Delia Corina Mihălțan ${ }^{2}$
}

\begin{abstract}
The object of the present paper is to answer the question regarding the sufficiency of the censorial control for a non-profit organization. In order to answer the question, we studied the specific literature and also the law and we tried to find the specific areas that should be the main objectives of a censorial control. The sufficiency of the censorial control in this case is conditioned by proper objective setting and these have to be none other than those specific for this sector. If the specific objectives are beyond the capacity of censorial control, its sufficiency is threatened.
\end{abstract}

Key words: censorial control, non-profit organization, specific objectives

JEL Code: $M 49$

\section{Introduction}

Financial information is produced both by the economic entities and the social ones. The need to assess their credibility and accuracy entails a control of the documents carrying such information and of the operations and transactions that generated them, control made by persons within the entity or by independent persons outside the entity. Censorial control as a type of financial control is part of the tools used to fulfill this need.

Considering that censorial control in non-profit organizations is required by the law and it involves measures to improve the patrimonial management, depending on the specific organization, its study is very important. Therefore, it is crucial to know the organization, its environment and the laws that apply to it.

Over time, societal development has resulted in varied situations involving specific issues and topics. Some of these cases have been solved by founding non-governmental organizations who took part in them, thus supporting more or less the authorities within the community in which their activity is developed. Non-profit organizations are non-governmental organizations, named by the law foundations, associations or federations according to their specificity. These entities operate under laws designed specifically to regulate their sphere of activity, the way in which their activity is developed, and their actions as entities that do not pursue profit.

From a legal perspective, the importance of censorial control within the non-profit organizations is defined by the regulation in force, which requires this type of control for the organization that does not audit the financial statements and / or organizations that manage public funds in a proportion smaller than $50 \%$ of the total.

In terms of written works, the censorial control for non-profit organizations is a relatively neglected area and considering the legal requirements, we believe that it is necessary that it be given some attention. With this paper we aim to address and present issues that would improve practice with regard to this type of control. They will refer to objectives specific to non-profit organizations that should be pursued in censorial control and the adequacy of such control against these

\footnotetext{
1 „1 Decembrie 1918” University of Alba Iulia, Romania, e-mail: ntodea@uab.ro

2 ,Valahia” University of Târgovişte, Romania,e-mail: dellya_c@yahoo.com
} 
objectives. We also address the place censorial control has in nonprofit organizations and its legal regulation.

\section{Research Methodology}

Research, as a methodical and systematical process of searching for topics of real interest, has as its purpose the acquisition of additional knowledge through the discovery of new facts and views on the studied issues. Scientific research is based on a point set on an "object" chosen to be investigated. (Cenar, 2010) Between the point of view and the object the method that will lead to a scientific idea is interposed as an instrument. The method consists of a systematic undertaking to investigate the reality on the subject of the study, namely those specific aspects of censorial control in the case of non-profit organizations.

Given the international changes in accounting and the gradual replacement of censorial control with other types of control or audit and the legal obligation for non-profit organizations to organize their censorial control, the question arises: "Under what conditions is this type of control adequate for non-profit organizations?".

In order to answer the previous question, we investigated the practice of censorial control and especially the specific objectives that should be followed within nonprofit organizations, and also the theoretical and legal aspects of censorial control.

We aimed to gather and process the information needed to define the context of the studied area and the identification of relational concepts represented by the basic concepts and the way censorial control is performed in the non-profit organizations. During the research we made use of methods, such as observation, reasoning, analysis, synthesis, interpretation, comparison in order to arrive to a better understanding of theoretical and practical issues of the subject under study. From a practical standpoint we studied the specific aspects of accounting within nonprofit organizations and emphasized their effects on censorial control, especially the objectives that must be considered during its development.

This paper is not intended to present an entire engagement of censorial control or a censorial report, but to highlight the specific objectives that need to be followed for this control to create added value within nonprofit organizations.

\section{Literature Review}

Theoretical and scientific support of the work is the research in the area of financial control in general and of censorial control in particular, therefore the research was performed based on literature. The literature for the non-profit organizations was also the subject of the study in order to understand their specifics regarding censorial control. An important role in writing the present paper was played by the regulation in force in the field of non-profit organizations, given that the literature is rather poor in treating similar topics. Below we present the issues addressed in the literature related to the subject of this paper, but also the results of the way of presenting censorial control in the literature we studied.

Control in its semantic meaning is a continuous or periodic analysis of activities, of a situation and so on in order to follow its progress and make necessary improvements. Activity control can be defined as a function of leadership, management tool, a means of knowing the reality and of correcting errors. Also, control is defined as the process of examining and measuring quantitative and qualitative achievement of performance, of tasks or work, which in turn need to be compared with planned objectives, indicating the necessary corrective measures. (Boulescu and Ghiță, 1997)

The objective of financial control is to examine the way in which the preset objectives have been or are being achieved, and the development of this process, whether or not the established principles have been observed, in order to reveal errors, deviations, deficiencies, weaknesses, 
correct them and avoid them in the future thus improving the course of the entity's activity.

Control, as an attribute of management and also as a system is manifested in various forms related to its content, reflecting the reality in general, essentially, and in particular, specifically. It does so in order to achieve its function of regulating the economic situation of the entity, in the context of structural and dynamic diversity. One of its many forms is censorial financial control.

From the point of view of several authors (Florea et al., 2007 and Teiuşan and Briciu, 2008) censorial control can now be considered as a combination of internal and external control of an entity. Explanation for this statement lies in the fact that Romanian legislator has prioritized the practices which existed before the Second World War, when the reconstruction of the market economy's legal system began. In this process the alert evolution of Western European countries and other capitalist countries was neglected. In the meantime these countries renounced this form of control replacing it more or less with internal and financial audit. The same authors argue that when we have a consolidated market economy, the censorial control will truly become an independent external control, being considered a part of the financial audit. Since these statements have been issued to this moment, the situation regarding the place and the role of censorial control does not seem to have changed.

From a historical point of view, the need for censorial control was felt by the founders of the entities that wanted to have some protection from the entity's management to whom it was entrusted. The censors were elected by the members and even from amongst them. Because of the complexity of economic relations censors were constrained to acquire some specialized training in order that the information provided by them would be meaningful to its users. The censors have specialized in accounting and later were recognized as professionals by the public administrative body or by the professional body. Thus, "the censors have become guarantors of reality, loyalty and credibility of accounting records for all external users of accounting information. The essential condition for meeting this requirement is for auditors to have a neutral stance on the entity and act as competent professionals, fully independent and responsible for their work and for their opinions." (Florea et.al., 2007)

Therefore, if we are to define censorial control, as it is presented in the literature, we could say that it is a form of financial control mainly aimed at verifying the patrimonial management and the drafting of financial statements and is exerted by persons outside the entity or by founders, the results being presented in a report by the censors.

\section{Results and discussions}

Implications of legal regulations regarding censorial control in nonprofit organizations

Nonprofit organizations are bound by the law to organize censorial control. The name "nonprofit organization" is generally used to refer to those entities that are not aimed to make a profit. These organizations, in legal terms, in Romania take the form of associations and foundations as defined in Law no. 246/2005 approving Government Ordinance no. 26/2000 on associations and foundations as presented in the following table:

Table no. 1

Definitions of types of nonprofit organizations in Romania

\begin{tabular}{|c|c|c|}
\hline \multicolumn{3}{|c|}{ The nonprofit organization types: } \\
\hline ASSOCIATION & FOUNDATION & FEDERATION \\
\hline $\begin{array}{c}\text { "is the legal entity formed by three or } \\
\text { more persons who, according to an } \\
\begin{array}{c}\text { agreement, are pooling and not subject to } \\
\text { refund material contribution, knowledge }\end{array}\end{array}$ & $\begin{array}{c}\text { "is the legal entity established by } \\
\text { one or more persons on the basis } \\
\text { of legal act between the living or } \\
\text { upon death and constitutes a }\end{array}$ & $\begin{array}{c}\text { is the body } \\
\text { established by the } \\
\text { association of two } \\
\text { or more }\end{array}$ \\
\hline
\end{tabular}


or contribution in labor with the purpose of carrying out activities in the general interest of some communities or, where appropriate, in their private prerogatives." patrimony permanently and irrevocably affected to achieve a goal of general interest or, as the case of some communities." associations /

foundations for

specific purposes

Source: author's construction based on law and literature

The main difference between the association and foundation relates to the role of patrimony. While the foundation achieves its purpose based on patrimony, association generally meets its objectives through voluntary work.

The importance of censorial control in the nonprofit organizations is growing relating to their number. In Romania, during the last period, their number has been growing. Their situation at the end of 2012 is presented in the following table:

Table no. 2

The numbers of nonprofit organizations in Romania by types

\begin{tabular}{|l|c|c|c|}
\hline \multicolumn{1}{|c|}{ Type } & Registered & $\begin{array}{c}\text { Closed or in the } \\
\text { process of being closed }\end{array}$ & Functioning \\
\hline Associations & 60,092 & 1,693 & 58,399 \\
\hline Foundations & 17,802 & 755 & 17,047 \\
\hline Federations & 699 & 5 & 694 \\
\hline
\end{tabular}

Source: author's construction based on data from The National Register of nonprofit organizatios

Crăciun (2003) states "regarding the associations and foundations, the censorial control institution is also characterized by their content and specific activity, which in principle is not an economic activity, but with a purpose falling within the statutory rules, namely association, support for humanitarian, social, professional or other purposes ."

Regarding the establishment and operation of nonprofit organizations, Government Ordinance 26/2000 on associations and foundations regulates the conditions under which they can legally develop their activity, defining and ensuring the rightful place for censorial control over these entities with a strong civic character because even if their activity is non for profit (social, humanitarian, cultural, etc.) they have to manage and control the material and financial resources held.

Documents underlying the formation of nonprofit organizations are The Constitutive Act and The Statute. In the content of The Statute it is required to present regulations related to the control of the activity in accordance with art. 16, section III of the said Ordinance, which provides that it must contain the responsibilities of the management, administration and control of the entity. Control is achieved by a censor or a censor committee, which represents a part of the organizational body.

The election and revoking of censors, or, where applicable, the members of the Censorial Committee (composed of an odd number of members), is the responsibility of the board of directors, that is the management and administration body of the Foundation.

The censorial control activity for nonprofit organizations is regulated by Art. 27 of the ordinance. Regulations regard the insurance of censorial control by a censor or a censorial committee, within associations with more than 100 members enrolled until the last general assembly meeting. The Commission shall be composed of an odd number of members, most of which consists of members, noting that people cannot censor if part of the Board. Censors operate under a mandate contract.

The main task of the auditor or auditing committee, in addition to what can be assigned by statute or by the General Assembly refers to verifying the way the patrimony is managed through the drawing of reports as a result of each censorial control. Reports will be submitted to the General 
Assembly and the censor or the censor committee may attend board meetings, but without having voting rights. The censor committee can choose to draw internal rules of operation; however, the general rules of organization and functioning of the Censorial Committee must be approved by the general meeting.

Regarding the conduct of censorial control and responsibilities of the persons in charge, the rules contain regulations for nonprofit organizations that are relatively similar to those of companies. In the case of nonprofit organizations the regulations are simplified, most likely because the activity they perform is not as complex as that of companies.

The fact that censorial control activity in the nonprofit sector is not as regulated as in the case of companies can generate the risk that its development is superficial, or it can be treated with indifference and as a consequence not achieve its objectives. Another fact that generates risk is that of incompatibilities which are not mentioned by the law, except for one. Thus the independence and impartiality of the censor can be threatened. However, legally the censor or the censor committee has to fulfill any duties established by the Statute or by the General Assembly. Thus we can say that the founders must provide and ensure the proper functioning of censorial control activity.

Given the good regulation of companies, censors may be tempted to act similarly in the case of nonprofit organizations. Indeed there are objectives relating to common elements in both areas of reference for censorial control. But the nonprofit sector has some particularities that ought not be forgotten and that should be assimilated by any person involved in such control, particularities which are not specified in legal regulations, but must be deducted. In the following table we will submit the main representative aspects that influence the control exercised by the censors:

Table no. 3

Specific aspects of nonprofit organizations

\begin{tabular}{|c|c|c|}
\hline \multirow{6}{*}{$\begin{array}{l}\text { Typical } \\
\text { aspects }\end{array}$} & \multirow{4}{*}{$\begin{array}{c}\text { related to the } \\
\text { object of } \\
\text { activity }\end{array}$} & The posibility of developing three types of activities \\
\hline & & Financing mainly by donations \\
\hline & & The existence of special funds \\
\hline & & Using volunteer human resources \\
\hline & \multirow[t]{2}{*}{ technical } & Working based on budget \\
\hline & & Specific method of profit taxation \\
\hline
\end{tabular}

Source: author's construction

As the table indicates, the typical aspects of nonprofit organizations are mainly related to the purpose they were established for, not to pursue profit but provide services of general interest, such as: social, cultural, humanitarian, educational, religious and so on. As such entities, non-profit organizations produce income in the form of donations received and expenses with donations through support in various fields. Therefore the censor or the censoring committee must consider the conditions under which donations are being received or granted and whether the operations or transactions of these donations are made in compliance with the terms of the contract.

Because of the purpose of their establishment, nonprofit organization is legally entitled to use voluntary labor while operating. Volunteering must be in compliance with the existing laws, namely Law No. 125/2001. An important regulation is the fact that a voluntary agreement should not replace an individual employment contract or other contracts. Nonobservance of this regulation results in the violation of the staff rights by the entity and is reflected on the organization's cash and cash equivalents. As a patrimonial integrity controller, the censor or the censoring committee is required to detect any irregularities regarding the conduct of volunteering.

An important aspect affecting the nonprofit organizations' specificity refers to the types of activities they can perform, namely: non-profit activity, economic activity, special activity. Nonprofit activities are the basic activities performed by the entity, pursuing the goals related to its 
establishment. Economic activity is related and in general is a commercial activity, developed in order to support or fund non-profit activity. Special activity relates to the activity that generates or uses certain funds that have a specific use, regulated by the law in force.

The existence of these three types of activities influences the accounting recognition of assets and liabilities, operations and transactions, namely they have to be recognized separately for each type of activity. This should be considered by censors during the censorial control, especially since the expenses, the income and the results are to be presented in the financial statements for each type of activity and overall.

Nonprofit organizations contain several categories of special funds according to the specific of the entity. The censors must determine if these funds were established and used in accordance with the regulation in force.

Since these entities are not pursuing profit the practice is for them to operate on a budget of income and expenses. The law does not clearly specify that non-profit organizations must have a budget, but at least for associations budgeting activity falls under the attributions of the General Assembly as listed in the Government Ordinance no. 26/2000. Censors should verify the development of budgeting activity and how the budgetary provisions were accomplished and must inspect especially budget revisions that occurred during the year and also their causes and consequences.

From a fiscal standpoint, non-profit organizations have specific regulations for calculating taxable profit. Article 15 of the Fiscal Code says that nonprofit organizations, trade unions and employers' organizations are exempt from tax on certain types of income (income from non-profit activities listed in the tax code), and for incomes up the equivalent in RON of EUR 15,000 in a fiscal year, but not more than $10 \%$ of total income exempt from tax. The censors must verify the correct application of this regulation during the calculation of taxable profit.

Of course, specific aspects of nonprofit organizations are diverse and are related to the field in which they operate. Our presentation is thus not exhaustive, but a general one, the particularities listed being present in most of these entities.

Following the censor control, the censor or the censor committee will draw a report that will be presented to shareholders. In the report the censors must present clearly and concisely the objectives pursued during the control, the techniques used and the results translated into recommendations where deficiencies are found. During the drawing of the report should be sought to increase its usefulness both to the founders and to the management. The auditors' report accompanies the financial statements set and thus becomes a public document that can raise interest from other users of financial information, other than founders and management.

\section{Conclusions and proposal}

Given the typical listed issues, one wonders whether the accounting implications are not beyond the competence of persons that exert the censorial control and whether this aspects should not be controlled by someone totally independent from the entity. Indeed, for non-profit organizations considered as being of public interest the law requires the audit of financial statements and hence internal audit organization, activities which manage the aspects mentioned more accurately. Also the nonprofit organizations that manage public funds in a proportion greater than $50 \%$ of the total are considered public entities, therefore are required to have an internal audit department. But what about the organizations not covered in any of the two categories mentioned above? Since for the latter censorial control is the only form of relatively external control exercised, it should cover all the key areas that generate risks associated to patrimonial integrity, and those areas where there is the risk to not comply to the regulations in force.

Currently, regulation of censorial control in this area is superficial, which does not favor its 
good development which may lead to the futility of censorial control and organizing it only to comply to the regulations in force, without bringing any value.

Our proposal is to find optimal solutions for censorial control in these non-profit organizations, solutions that would improve censorial control or why not, even replacing it with the audit activity, given how the exercise of censorial control begun in our country in the 1990's. Since the regulations in force allow the Censorial Committee to draw up its own rules of operation, we propose the setting of objectives that would address specific aspects of the non-profit organizations they serve. These aspects together with their specific activities (social, humanitarian, cultural etc.) held by nonprofit organizations are characterizing the censorial control for this type of entities and thus distinguishes it from censorial control exercised in companies. This is the main reason for which the way censorial control is developed should not be treated with neglect, but on the contrary, it is required to be given importance.

\section{References}

1. Boulescu M., Ghiță M., 1997. Control financiar, Bucharest, Eficient Publishing House

2. Briciu S. (eds.), 2003. Controlul şi expertiza-instrumente de apărare a patrimoniului şi de respectare a legalității, Cluj Napoca, Risoprint Publishing House

3. Crăciun Ş., 2002, Controlul şi auditul financiar. Expertiza contabilăa, Bucharest, Economică Publishing House

4. Florea I., Macovei I.C., Florea R., 2007. Controlul economic, financiar şi gestionar, Bucharest, CECCAR Publishing House

5. Florea I, Florea R., Macovei I.C., Berheci M., 2008. Introducere în expertiza contabilă şi în auditul financiar, $2^{\text {nd }}$ edition, Bucharest, CECCAR Publishing House

6. Pereş I., Popa E., Bunget O., Dumitrescu C., 2008. Control financiar, Timişoara, Mirton Publishing House

7. Popeangă P., Popeangă G., 2004. Controlul financiar şi fiscal, Bucharest, CECCAR Publishing House

8. Todea N., 2009. Teorie contabilă şi raportare financiară, Alba Iulia, Aeternitas Publishing House

9. Teiuşan S.C., Briciu S., 2008. Between the external control and the intern control, Annals of University of Oradea, Ec. Science Series, Vol. 17, Issue3, pp.1496-1499.

10. *** Law no. 246 approving Government Ordinance no. 26/2000 on associations and foundations, published in (2005) Official Monitor of Romania no. 656.

11. *** Law no. 125 regarding volunteering republished in (2007) Official Monitor of Romania no. 276.

12.*** Law no. 571 of 22 December 2003 regarding the Fiscal Code, as amended and completed, republished.

13. The National Register of nonprofit organizatios:

http://www.just.ro/MinisterulJusti\%C8\%9Biei/RegistrulNa\%C5\%A3ionalONG/tabid/91/Default.aspx. 